\title{
PENGARUH SISTEM OLAH TANAH DAN APLIKASI HERBISIDA TERHADAP BIOMASSA KARBON MIKROORGANISME TANAH (C-MIK) PADA PERTANAMAN JAGUNG (Zea mays L.) MUSIM TANAM KE-5 DI GEDONG MENENG
}

\author{
EFFECT OF SOIL TILLAGE SYSTEM AND HERBICIDE APPLICATION ON \\ SOIL MICROBIAL BIOMASS CARBON (C-mic) IN CORN (Zea mays L.) \\ PLANTATION AT GEDONG MENENG
}

\author{
I Gde Agung Indrayuana Giri, Sri Yusnaini, Jamalam Lumbanraja \& Henrie Buchari \\ Jurusan Agroteknologi, Fakultas Pertanian, Universitas Lampung \\ Jl. Prof. Dr. Soemantri Brodjonegoro No. 1 Bandar Lampung 35145 \\ Email: Indrayuanaagung79@gmail.com
}

\begin{abstract}
Soil microbial carbon biomass (C-mic) is an indicator to determine the amount of microbial biomass that has a role to measure soil microbial activity. This research aimed to study the effect of soil tillage system, herbicide application and their interaction on soil microbial carbon biomass. The experiment was a factorial, randomized block design, with 4 replications. The first factor was soil tillage system that consist of minimum tillage (TO) and full tillage (T1); while the second factor was herbicide application (H) consisting of non-herbicide (HO) and herbicide (H1). Analysis of variance (anova) was carried out using a significance level of 0.05 after verifying the additivity (Tukey's test) and homogeneity of variance (Bartlett's test) of the data. When a significant effect was revealed in the anova, the mean separations among treatments were obtained by least significant difference (LSD 0.05). Correlation test was carried out to find out the relationship between soil microbial carbon biomass with organic carbon, $\mathrm{pH}$, soil water content, and soil temperature. The results showed that soil tillage system had no significant effect on soil microbial carbon biomass. While herbicide application (H1) affected higher amount of soil microbial carbon biomass (C-mic) than non-herbicide (HO) on the vegetative maximum phase of the corn. There was no interaction between soil tillage system and herbicide application on soil microbial carbon biomass.
\end{abstract}

Keywords: Herbicide, soil microbial biomass carbon (C-mic), soil tillage system.

\begin{abstract}
ABSTRAK
Biomassa karbon mikroorganisme tanah (C-mik) merupakan indikator untuk mengetahui jumlah biomassa mikroorganisme yang berperan untuk mengukur aktivitas dari mikroorganisme di dalam tanah. Penelitian ini bertujuan untuk mempelajari pengaruh olah tanah dan aplikasi herbisida serta interaksinya terhadap biomassa karbon mikroorganisme tanah (C-mik). Penelitian dilakukan dengan menggunakan rancangan acak kelompok (RAK) yang disusun secara faktorial dengan 4 kombinasi perlakuan dan 4 ulangan. Faktor pertama adalah sistem olah tanah yaitu $\mathrm{T}_{0}=$ Olah Tanah Minimum, $\mathrm{T}_{1}=$ Olah Tanah Sempurna dan faktor kedua adalah aplikasi herbisida yaitu $\mathrm{H}_{0}=$ Tanpa Aplikasi Herbisida, dan $\mathrm{H}_{1}=$ Aplikasi Herbisida. Data yang diperoleh diuji homogenitas
\end{abstract}


ragam dengan uji bartlett dan aditifitasnya dengan uji tukey setelah asumsi terpenuhi data diolah dengan analisis ragam dan dilanjutkan dengan uji beda nyata terkecil (BNT) pada taraf $5 \%$. Hubungan antara biomassa karbon mikroorganisme tanah dengan C-organik, $\mathrm{pH}$, kadar air tanah, dan suhu tanah dilakukan uji korelasi. Hasil penelitian menunjukkan bahwa perlakuan sistem olah tanah tidak berpengaruh nyata terhadap biomassa karbon mikroorganisme tanah. Sedangkan perlakuan aplikasi herbisida memberikan jumlah biomassa karbon mikroorganisme tanah (C-mik) lebih tinggi daripada tanpa aplikasi herbisida pada pengamatan fase vegetatif maksimum tanaman. Tidak terdapat interaksi antara sistem pengolahan tanah dan aplikasi herbisida terhadap biomassa karbon mikroorganisme tanah.

Kata Kunci : Biomassa karbon mikroorganisme (C-mik), sistem olah tanah, herbisida.

\section{PENDAHULUAN}

Degradasi tanah dapat terjadi karena kesalahan dalam pengolaan tanah. Usaha yang dapat dilakukan untuk mempertahankan produktivitas tanah, diantaranya adalah melalui modifikasi cara olah tanah dan intensitas pengolahan tanah (Fuady, 2010). Pemadatan tanah yang banyak terjadi akibat olah tanah intensif (OTI) harus dihindari, agar tanah dapat memenuhi syarat sebagai tempat pertumbuhan dan perkembangan akar tanaman serta menunjang kehidupan mikroorganisme tanah. Salah satu cara mengurangi pemadatan tanah adalah dengan pengolahan tanah. Pengolahan tanah dapat dilakukan dengan beberapa metode tergantung tingkat kepadatan tanah dan tingkat porositas tanah yang diinginkan. Pemilihan beberapa metode pengolahan tanah sangat tergantung pada tingkat kepadatan tanah dan porositas tanah yang diinginkan. Pengolahan yang biasa dilakukan adalah olah tanah intensif(konvensional), olah tanah minimum(OTM), dan tanpa olah tanah (TOT) (Salam, 2012).

Penggunaan sistem olah tanah intensif(OTI) yang berdampak pada tingginya erosi mendorong petani mulai menerapkan sistem olah tanah konservasi (Utomo, 1990). Umumnya yang sering diterapkan adalah olah tanah minimum(OTM). Penerapan sistem olah tanah konservasi jangka panjang dinilai dapat meningkatkan bahan organik tanah. Kandungan bahan organik mempengaruhi kesuburan tanah dan mikroorganisme membutuhkan bahan organik sebagai sumber energi dalam pertumbuhannya. Rao (1994) menyatakan bahwa akar tanaman mengeluarkan eksudat berupa asam-asam organik, asam amino, gula protein, polisakarida dan senyawa lain yang belum teridentifikasi. Eksudat akar yang dikeluarkan oleh akar tanaman akan merangsang meningkatnya populasi mikroorganisme tanah yang merupakan sumber biomassa mikroorganisme tanah. Selain bersumber dari eksudat akar, penambahan pupuk organik dan pembiaran serasah tanaman pada lahan pertanaman juga dapat menjadi sumber bahan organik lain yang bermanfaat bagi mikroorganisme tanah.

Aplikasi herbisida merupakan bagian tak terpisahkan dalam kegiatan pengolahan tanah baik pada sistem olah tanah intensif maupun sistem olah tanah konservasi, herbisida akan berpengaruh terhadap 
aktivitas mikroorganisme tanah terutama jika diaplikasikan berulang kali selama bertahun-tahun. Menurut Dermiyati (1997) sebagian besar herbisida yang diaplikasikan ke tanaman akhirnya akan jatuh ke tanah dan menjadi residu yang beracun dalam tanah dapat membunuh mikroorganisme tanah, yang sebenarnya bukan targetnya sehingga mengganggu aktivitas mikroorganisme tanah yang pada akhirnya dapat mempengaruhi siklus hara di dalam tanah.

Menurut Jenkinson dan Powlson (1976), biomassa mikroorganisme tanah merupakan bagian hidup dari bahan organik tanah di luar akar-akar tanaman dan fauna tanah. Mikroorganisme tanah sangat berperan penting dalam proses-proses yang terjadi di dalam tanah, contohnya seperti siklus karbon dan ketersediaan hara. Dalam perbaikan tanah, perlu diketahui biomassa mikroorganisme tanah oleh karena itu dilakukan penelitian ini untuk mengetahui jumlah biomassa karbon mikroorganisme tanah (C-mik).

\section{BAHAN DAN METODE}

Penelitian dilaksanakan dari bulan Oktober 2016 sampai Januari 2017 pada lahan percobaan di Laboratorium Lapang Terpadu, Fakultas Pertanian, Universitas Lampung. Analisis biomassa karbon mikroorganisme (C-mik) dilakukan di Laboratorium Bioteknologi Pertanian dan analisis sampel tanah dilakukan di Laboratorium Ilmu Tanah, Fakultas Pertanian, Universitas Lampung.

Rancangan yang digunakan dalam penelitian ini adalah rancangan acak kelompok (RAK) yang disusun secara faktorial yang terdiri dari dua faktor yaitu sistem olah tanah dan aplikasi herbisida. Sistem olah tanah terdiri dari olah tanah minimum $\left(\mathrm{T}_{\mathrm{a}}\right)$ dan olah tanah intensif $\left(\mathrm{T}_{1}\right)$. Sedangkan aplikasi herbisida terdiri dari tanpa aplikasi herbisida $\left(\mathrm{H}_{0}\right)$ dan aplikasi herbisida $\left(\mathrm{H}_{1}\right)$. Dengan demikian terbentuk empat kombinasi perlakuan yaitu :

$\mathrm{T}_{0} \mathrm{H}_{\mathrm{a}}=$ olah tanah minimum + tanpa aplikasi herbisida $\mathrm{T}_{0} \mathrm{H}_{1}=$ olah tanah minimum + aplikasi herbisida $\mathrm{T}_{1} \mathrm{H}_{\mathrm{a}}=$ olah tanah intensif + tanpa aplikasi herbisida $\mathrm{T}_{1} \mathrm{H}_{1}=$ olah tanah intensif + aplikasi herbisida Setiap perlakuan dulang sebanyak empat kali, sehingga diperoleh 16 satuan percobaan.

Variabel yang diamati terdiri dari variabel utama yaitu biomassa karbon mikroorganisme tanah (C-mik) dan variabel pendukung yaitu kadar air tanah, Corganik, suhu tanah dan $\mathrm{pH}$ tanah. Data yang diperoleh diuji homogenitas ragam dengan uji bartlett dan aditifitasnya dengan uji tukey setelah asumsi terpenuhi data diolah dengan analisis ragam dan dilanjutkan dengan uji beda nyata terkecil (BNT) pada taraf $5 \%$. Hubungan antara biomassa karbon mikroorganisme tanah dengan C-organik, pH, kadar air tanah, dan suhu tanah dilakukan uji korelasi.

\section{HASIL DAN PEMBAHASAN}

Pengaruh Sistem Olah Tanah dan Aplikasi Herbisida terhadap Biomassa Karbon Mikroorganisme Tanah (C-mik)

Hasil analisis ragam pengamatan biomassa karbon mikroorganisme tanah (C-mik) pada fase sebelum olah tanah, fase setelah olah tanah, fase 
vegetatifmaksimum tanaman dan fase generatif tanaman (Tabel 1) menunjukkan bahwa perlakuan pengolahan tanah tidak berpengaruh nyata terhadap biomassa karbon mikroorganisme tanah (C-mik) pada semua fase pengamatan. Sedangkan pada perlakuan aplikasi herbisida berpengaruh nyata terhadap biomassa karbon mikroorganisme tanah (C-mik) pada fase vegetatif maksimum tanaman. Interaksi antara perlakuan pengolahan tanah dan aplikasi herbisida pada semua pengamatan tidak berpengaruh nyata terhadap biomassa karbon mikroorganisme tanah (C-mik). Hasil uji lanjut BNT 5\% menunjukan perlakuan herbisida menghasilkan nilai biomassa karbon mikroorganisme tanah (C-mik) lebih tinggi dibandingkan dengan perlakuan tanpa herbisida.

Perlakuan sistem olah tanah tidak berpengaruh nyata terhadap biomassa karbon mikroorganisme tanah (C-mik) karena jangka waktu penelitian yang terlalu singkat diduga menjadi faktor utama belum terlihatnya pengaruh perlakuan sistem olah tanah terhadap biomassa karbon mikroorganisme tanah (C-mik). Hal ini sejalan dengan penelitian Pratiwi (2013) yang menyatakan bahwa dalam kurun waktu yang singkat penerapan perlakuan sistem olah tanah belum memperlihatkan pengaruh yang nyata terhadap biomassa karbon mikroorganisme tanah (C-mik). Proses peningkatan karbon dalam tanah pertanian sangat lambat. Hasil percobaan di berbagai tempat di Amerika Serikat menunjukkan bahwa untuk mencapai karbon dalam tanah pada kondisi keseimbangan memerlukan waktu sekitar 20-30 tahun (Duxburry, 2007). Di Indonesia, di samping proses pengikatan karbon dalam tanah sangat lambat, untuk memperoleh data dari penelitian jangka panjang lebih dari 20 tahun juga sangat sulit (Utomo, 2012(b)).

Sedangkan pada perlakuan aplikasi herbisida menunjukkan pengaruh nyata terhadap biomassa karbon mikroorganisme tanah (C-mik) pada fase

Tabel 1. Pengaruh pengolahan tanah dan aplikasi herbisida terhadap biomassa karbon mikroorganisme tanah (C-mik) mg C- $\mathrm{CO}_{2} 100 \mathrm{~g}^{-1}$ hari $^{-1}$ pada fase sebelum olah, setelah olah, vegetatif maksimum tanaman dan generatif tanaman

\begin{tabular}{|c|c|c|c|c|}
\hline \multirow{2}{*}{ Perlakuan } & Sebelum Olah & Setelah Olah & Fase Vegetatif Maksimum & Fase Generatif \\
\hline & \multicolumn{4}{|c|}{$\ldots \ldots \ldots . . . . \mathrm{mg} \mathrm{C}-\mathrm{CO}_{2} 100 \mathrm{~g}^{-1}$ hari $^{-1} \ldots \ldots \ldots$} \\
\hline $\mathrm{T}_{0} \mathrm{H}_{0}$ & 79,17 & 40,17 & 40,02 & 56,70 \\
\hline $\mathrm{T}_{0} \mathrm{H}_{1}$ & 80,49 & 46,10 & 60,00 & 53,26 \\
\hline $\mathrm{T}_{1} \mathrm{H}_{0}$ & 57,29 & 40,17 & 46,03 & 43,02 \\
\hline $\mathrm{T}_{1} \mathrm{H}_{1}$ & 73,32 & 35,56 & 61,32 & 55,17 \\
\hline Sumber Keragaman & \multicolumn{4}{|c|}{ F Hitung dan Signifikan } \\
\hline $\mathrm{T}$ & $2,95^{\text {tn }}$ & $0,55^{\text {tn }}$ & $0,44^{\mathrm{tn}}$ & $1,07^{\text {tn }}$ \\
\hline $\mathrm{H}$ & $1,05^{\mathrm{tn}}$ & $0,008^{\mathrm{tn}}$ & $10,26^{*}$ & $0,58^{\mathrm{tn}}$ \\
\hline $\mathrm{T} X \mathrm{H}$ & $0,75^{\text {tn }}$ & $0,55^{\mathrm{tn}}$ & $0,18^{\mathrm{tn}}$ & $1,87^{\text {tn }}$ \\
\hline
\end{tabular}

Keterangan $:$ tn $=$ tidak berpengaruh nyata pada taraf $5 \% ; *=$ Berbeda nyata pada taraf $5 \% ; \mathrm{T}=$ Pengolahan Tanah; $\mathrm{H}=$ Herbisida; $\mathrm{T} \mathrm{X} \mathrm{H}=$ Interaksi antara pengolahan tanah dan herbisida 
Tabel 2. Uji BNT perlakuan aplikasi herbisida terhadap biomassa karbon mikroorganisme tanah (C-mik) pada fase vegetatif maksimum tanaman

\begin{tabular}{cc}
\hline Perlakuan & C-mik $\left(\right.$ mg C-CO $100 \mathrm{~g}^{-1}$ hari $\left.^{-1}\right)$ \\
\hline Tanpa Herbisida & $43,02 \mathrm{a}$ \\
Herbisida & $60,67 \mathrm{~b}$ \\
\hline BNT $5 \%$ & 17,61 \\
\hline
\end{tabular}

Keterangan : Angka yang diikuti oleh huruf yang sama tidak berbeda nyata dengan uji BNT pada taraf 5

vegetatif maksimum tanaman (Tabel 2). Hal ini diduga disebabkan oleh pengaplikasian herbisida berbahan aktif isopropilamina glisofat $+2,4 \mathrm{D}$ yang efektif mematikan rumput tahunan, gulma daun lebar, dan gulma yang memiliki perakaran dalam yang kemudian terakumulasi kemudian akan mengalami proses dekomposisi serta meningkatkan kandungan bahan organik tanah. Nursyamsi, dkk., (1996) menyatakan bahwa bahan organik merupakan sumber energi bagi mikroorganisme tanah. Oleh karena itu semakin banyak bahan organik yang tersedia di dalam tanah, maka populasi mikroorganisme tanah juga semakin meningkat. Selain itu mikroorganisme di dalam tanah menggunakan semua bahan organik di dalam tanah untuk bahan makanannya termasuk juga herbisida. Mikroorganisme mampu merubah dan menghancurkan molekul-molekul yang mengakibatkan penonaktifan bahan kimia dari herbisida. Proses ini disebut dekomposisi mikrobial (Anderson, 1983).

Mikroorganisme mampu mendegradasikan glifosat melalui dua cara yaitu melalui jalur sarkosin atau asam aminometilfosfonat (AMPA). Mikroorganisme memutuskan ikatan C-P dari glifosat menghasilkan fosfonat dan sarkosin. Selanjutnya fosfonat digunakan oleh mikroorganisme sebagai sumber fosfor untuk kehidupannya sedangkan sarkosin digunakan sebagai sumber karbon untuk menghasilkan glisin. Selain itu, Mikroorganisme memutuskan ikatan C-N pada struktur glifosat dan memanfaatkannya sebagai sumber karbon dengan menghasilkan AMPA (Fan, dkk., 2012).

Pengaruh akar-akar tanaman pada fase vegetatif maksimum didugajuga mampu memberikan sumbangan terhadap peningkatan karbon di dalam tanah. Selain bersumber dari akar-akar tanaman, beberapa penambahan seperti pupuk organonitrofos dan serasah tanaman pada lahan pertanaman juga menjadi sumber bahan organik yang bermanfaat bagi mikroorganisme tanah.

\section{Pengaruh Pengolahan Tanah dan Aplikasi} Herbisida Terhadap Kadar Air Tanah, Suhu

\section{Tanah, C-organik dan pH Tanah}

Hasil analisis ragam pengaruh pengolahan tanah dan aplikasi herbisida terhadap beberapa sifat tanah (Tabel 3) menunjukkan bahwa pada perlakuan aplikasi herbisida berpengaruh nyata terhadap kadar air tanah pada fase vegetatif maksimum tanaman dan suhu tanah pada fase generatif tanaman.

Berdasarkan hasil uji BNT pada taraf 5\% 
Tabel 3. Pengaruh sistem olah tanah dan pengaplikasian herbisida terhadap beberapa sifat tanah pada pertanaman jagung (Zea Mays L.) musim tanam ke-5 di Gedong meneng pada pengamatan fase vegetatif maksimum dan generatif tanaman

\begin{tabular}{lccccccc}
\hline \multirow{2}{*}{ Sumber Keragaman } & \multicolumn{5}{c}{ F-hitung Variabel Pengamatan } \\
\cline { 2 - 7 } & \multicolumn{2}{c}{ Kadar Air (\%) } & \multicolumn{2}{c}{ Suhu Tanah $\left({ }^{\circ} \mathrm{C}\right)$} & C-organik $(\%)$ & $\mathrm{pH}\left(\mathrm{H}_{2} \mathrm{O}\right)$ \\
\cline { 2 - 7 } & $\begin{array}{c}\text { Vegetatif } \\
\text { Maksimum }\end{array}$ & Generatif & $\begin{array}{c}\text { Vegetatif } \\
\text { Maksimum }\end{array}$ & Generatif & Generatif & $\begin{array}{c}\text { Vegetatif } \\
\text { Maksimum }\end{array}$ & Generatif \\
\hline Kelompok & $0,48^{\text {tn }}$ & $2,23^{\text {tn }}$ & $0,91^{\text {tn }}$ & $17,45^{*}$ & $0,46^{\text {tn }}$ & $1,13^{\text {tn }}$ & $1,08^{\text {tn }}$ \\
Pengolahan Tanah (T) & $0,02^{\text {tn }}$ & $1,54^{\text {tn }}$ & $2,46^{\text {tn }}$ & $1,09^{\text {tn }}$ & $3,52^{\text {tn }}$ & $0,05^{\text {tn }}$ & $5,85^{\text {tn }}$ \\
Herbisida (H) & $8,93^{\text {tn }}$ & $0,38^{\text {tn }}$ & $0,07^{\text {tn }}$ & $13,36^{*}$ & $0,57^{\text {tn }}$ & $0,80^{\text {tn }}$ & $0,15^{\text {tn }}$ \\
T X H & $0,03^{\text {tn }}$ & $1,09^{\text {tn }}$ & $2,00^{\text {tn }}$ & $0,27^{\text {tn }}$ & $0,13^{\text {tn }}$ & $1,08^{\text {tn }}$ & $2,28^{\text {tn }}$ \\
\hline
\end{tabular}

Keterangan : tn $=$ tidak berbeda nyata pada taraf $5 \% ; *=$ berbeda nyata pada taraf $5 \%$; $\mathrm{T} \mathrm{X} \mathrm{H}=$ Interaksi antara pengolahan tanah dan herbisida.

Tabel 4. Uji BNT perlakuan aplikasi herbisida terhadap suhu tanah pada fase generatif tanaman dan kadar air tanah pada fase vegetatif maksimum tanaman

\begin{tabular}{lcc}
\hline Perlakuan $\mathrm{H}$ & Suhu Tanah $\left({ }^{\circ} \mathrm{C}\right)$ & Kadar Air $(\%)$ \\
\hline Tanpa Herbisida & $27,97 \mathrm{~b}$ & $27,56 \mathrm{a}$ \\
Herbisida & $27,79 \mathrm{a}$ & $30,60 \mathrm{~b}$ \\
\hline BNT 5\% & 0,17 & 2,49 \\
\hline
\end{tabular}

Keterangan : Angka yang diikuti oleh huruf yang sama tidak berbeda nyata dengan uji BNT pada taraf 5

perlakuan aplikasi herbisida terhadap suhu tanah pada fase generatif tanaman dan kadar air tanah pada fase vegetatif maksimum tanaman (Tabel4) menunjukkan bahwa perlakuan aplikasi herbisida menghasilkan nilai kadar air tanah lebih tinggi dibandingkan dengan perlakuan tanpa aplikasi herbisida. Sedangkan suhu tanah terlihat bahwa perlakuan tanpa aplikasi herbisida memiliki besaran suhu tanah $\left({ }^{\circ} \mathrm{C}\right)$ lebih tinggi dibandingkan dengan perlakuan aplikasi herbisida. Berdasarkan hasil statistik kedua perlakuan tersebut memperlihatkan perbedaan yang nyata, namun sebenarnya jika dilihat dari segi ekologis kedua pelakuan tersebut dapat dikatakan tidak berbeda nyata. Sedangkan untuk kadar air tanah menunjukkan perlakuan dengan aplikasi herbisida memiliki kadar air tanah (\%) lebih tinggi dibandingkan dengan perlakuan tanpa aplikasi herbisida. Hal ini diduga karena herbisida yang diaplikasikan pada petak pengamatan mampu mematikan gulma dan menutupi permukaan tanah sehingga mampu mengurangi penguapan di dalam tanah dan menyebabkan kadar air tanah meningkat.

Sifat Tanah Awal Sebelum Perlakuan dan Akhir Penelitian serta Korelasi antara Kadar Air Tanah, Suhu Tanah, C-organik dan pH Tanah dengan Biomassa Karbon Mikroorganisme Tanah (Cmik)

Data hasil analisis awal sebelum perlakuan dan 
pengamatan akhir penelitian terhadap beberapa sifat tanah yaitu kadar air tanah, C-organik, $\mathrm{pH}$ tanah dan suhu tanah (Tabel 5) menunjukkan bahwa terjadi penurunan kandungan $\mathrm{C}$-organik tanah sebesar 0,4\% dari hasil analisis tanah sebelum penelitian. Hal ini terjadi diduga karena kandungan $\mathrm{C}$-organik tanah pada pertanaman telah mengalami proses dekomposisi sehingga jumlah C-organik mengalami penurunan. Selanjutnya suhu tanah pada saat sebelum penelitian dan saat pengamatan akhir mengalami sedikit penurunan. Penurunan suhu tersebut diduga dikarenakan suhu lingkungan sekitar yang rendah dan vegetasi tanaman yang berada di atas tanah pada saat pengambilan sampel saat pengamatan akhir lebih banyak dibandingkan pada saat di sebelum penelitian.

Untuk nilai $\mathrm{pH}$ tanah juga mengalami sedikit penurunan dan masih tergolong agak asam. Kondisi tersebut diduga dipengaruhi oleh curah hujan yang menyebabkan tanah pertanaman menjadi asam. Menurut Johnshon (1914), Curah hujan yang berlebihan dapat menghilangkan kation dasar selama periode waktu yang lama. Curah hujan juga paling efektif dalam menyebabkan tanah menjadi asam jika banyak air bergerak melalui tanah dengan cepat. Selain hal tersebut proses dekomposisi bahan organik oleh mikroorganisme juga dapat mengakibatkan $\mathrm{pH}$ tanah menjadi rendah. Selanjutnya, nilai kadar air tanah mengalami peningkatan sebanyak 5,70\%. Hal ini diduga karena lingkungan sekitar saat pengambilan sampel tanah lebih lembab karena adanya vegetasi tanaman maupun gulma yang menutupi permukaan tanah sehingga mempengaruhi kadar air tanah.

Selanjutnya, hasil uji korelasi antara biomassa karbon mikroorganisme tanah (C-mik) dengan pengamatan kadar air tanah $(\%)$, suhu tanah $\left({ }^{\circ} \mathrm{C}\right), \mathrm{C}$ organik (\%) dan $\mathrm{pH}$ tanah (Tabel 6) menunjukkan bahwa biomassa karbon mikroorganisme tanah (Cmik) tidak menunjukkan korelasi terhadap beberapa sifat tanah pada fase vegetatifmaksimum dan generatif tanaman yang artinya nilai biomassa karbon mikroorganisme tanah (C-mik) tidak dipengaruhi oleh sifat-sifat tanah tersebut.

Dari hasil uji korelasi (Tabel 6) kadar air tidak memberikan pengaruh yang nyata terhadap biomassa karbon mikroorganisme tanah (C-mik) pada fase vegetatif maksimum maupun fase generatif tanaman. Hal ini terjadi karena mikroorganisme membutuhkan kondisi yang optimum untuk

Tabel 5. Hasil analisis tanah sebelum penelitian dan pengamatan akhir penelitian di lahan pertanaman yang diambil dari rata-rata pada perlakuan $\mathrm{T}_{0} \mathrm{H}_{0}$

\begin{tabular}{lcc}
\hline \multicolumn{1}{c}{ Jenis Analisis } & \multicolumn{2}{c}{ Hasil Analisis } \\
\cline { 2 - 3 } & Sebelum Perlakuan & Pengamatan Akhir \\
\hline Kadar air tanah $(\%)$ & 30,9 & 36,6 \\
Suhu tanah $\left({ }^{\circ} \mathrm{C}\right)$ & 28,3 & 28,0 \\
C-organik $(\%)$ & 2,1 & 1,7 \\
$\mathrm{pH}\left(\mathrm{H}_{2} \mathrm{O}\right)$ & 6,4 & 6,3 \\
\hline
\end{tabular}


Tabel 6. Hasil uji korelasi beberapa sifat tanah (kadar air tanah, suhu tanah, C-organik dan $\mathrm{pH}$ tanah) dengan biomassa karbon mikroorganisme tanah (C-mik) pada fase vegetatif maksimum dan generatif tanaman

\begin{tabular}{|c|c|c|}
\hline \multirow{3}{*}{ Variabel } & \multicolumn{2}{|c|}{ Koefisien Korelasi (r) } \\
\hline & \multicolumn{2}{|c|}{ C-mik (mg C-CO ${ }_{2} 100 \mathrm{~g}^{-1}$ hari $^{-1}$ ) } \\
\hline & Fase Vegetatif Maksimum & Fase Generatif \\
\hline Kadar Air (\%) & $0,53^{\text {tn }}$ & $0,26^{\mathrm{tn}}$ \\
\hline Suhu Tanah $\left({ }^{\circ} \mathrm{C}\right)$ & $0,24^{\text {tn }}$ & $0,01^{\mathrm{tn}}$ \\
\hline C-organik (\%) & Tidak ada data & $0,34^{\mathrm{tn}}$ \\
\hline $\mathrm{pH}\left(\mathrm{H}_{2} \mathrm{O}\right)$ & $0,14^{\mathrm{tn}}$ & $0,35^{\mathrm{tn}}$ \\
\hline
\end{tabular}

Keterangan : $\mathrm{tn}=$ tidak berkorelasi nyata pada taraf $5 \%$

pertumbuhan hidupnya. Kadar air yang baik bagi pertumbuhan mikroorganisme tanah berkisar antara 40 $-60 \%$. Kadar air pada lahan penelitian ini hanya sekitar $30 \%$. Rendahnya kadar air tanah tersebut dipengaruhi oleh faktor eksternal yaitu kondisi linkungan sekitar pertanaman. Selain hal tersebut kadar air tanah tidak berpengaruh nyata terhadap C-mik tanah dikarenakan penerapan olah tanah intensif (OTI) yang mengakibatkan tanah terdegradasi sehingga kadar air tanah mengalami penurunan. Menurut Utomo (2012(a)), olah tanah intensif(OTI) menyebabkan laju evaporasi yang cukup tinggi sehingga mengakibatkan kekeringan pada tanah.

Hasil uji korelasi suhu tanah tidak memberikan pengaruh yang nyata terhadap C-mik tanah pada fase vegetatif maksimum maupun fase generatif tanaman. Suhu tanah yang optimum akan mendukung pertumbuhan mikroorganisme tanah, oleh karena itu apabila suhu tanah tidak sesuai dengan karakteristik mikroorganisme maka akan mempengaruhi pertumbuhannya. Selain itu Menurut Lubis (2007) Suhu tanah ditentukan dengan interaksi dari beberapa faktor yaitu faktor eksternal (lingkungan) dan internal (tanah). Faktor lingkungan diantaranya radiasi matahari, radiasi dari awan, konduksi panas dari atmosfer, kondensasi, penguapan, curah hujan dan vegetasi. Sedangkan faktor internal dalam tanah diantaranya keterhantaran dan difusivitas tanah, kapasitas panas, aktivitas biologi, radiasi matahari, struktur, tekstur dan kelembaban dan gram-gram terlarut. Akibatnya suhu di dalam tanah yang diberikan perlakuan sistem olah tanah dan aplikasi herbisida tersebut dapat berubah tergantung dari beberapa faktor yang mempengaruhinya baik faktor eksternal maupun internal.

Hasil uji korelasi C-organik tanah tidak memberikan pengaruh yang nyata terhadap C-mik tanah pada fase generatif tanaman. Pengolahan tanah, aplikasi herbisida dan interaksi keduanya tidak berpengaruh terhadap $\mathrm{C}$-organik tanah pada kedalaman 0 sampai $20 \mathrm{~cm}$. Hal ini menunjukkan bahwa kandungan C-organik tanah pada setiap perlakuan telah banyak mengalami dekomposisi sehingga Corganik tanahnya pun menurun dan kandungannya relatif sama antar setiap perlakuan. 
Hasil uji korelasi $\mathrm{pH}$ tanah tidak memberikan pengaruh yang nyata terhadap $\mathrm{C}$-mik tanah pada fase vegetatif maksimum maupun fase generatif tanaman. Hal ini karena pada umumnya mikroorganisme dapat tumbuh dengan baik pada $\mathrm{pH} 7$ (netral) meskipun dapat tumbuh pada kisaran $\mathrm{pH} 5-8$. Selain itu $\mathrm{pH}$ tanah mempengaruhi perkembangan mikroorganisme tanah pada kondisi tanah yang berbeda (Sumarsih, 2003).

\section{KESIMPULAN}

Perlakuan sistem olah tanah tidak berpengaruh nyata terhadap biomassa karbon mikroorganisme tanah (Cmik) pada semua fase pengamatan. Perlakuan aplikasi herbisida memberikan jumlah biomassa karbon mikroorganisme tanah (C-mik) lebih tinggi daripada tanpa aplikasi herbisida pada pengamatan fase vegetatif maksimum tanaman. Tidak terdapat interaksi antara sistem olah tanah dan aplikasi herbisida terhadap biomassa karbon mikroorganisme tanah (C-mik) pada semua fase pengamatan.

\section{DAFTAR PUSTAKA}

Anderson, W. P. 1983. Weed Science: Principles. Second Edition. United Kingdom. $228 \mathrm{hlm}$.

Dermiyati. 1997. Effects of mulch application on soil microorganism activities and yield of corn. J. Tropical Soil. 5:63-68.

Duxburry, J.M. 2007. Soil carbon sequestration and nutrient management for greenhouse gas mitigation. Dept. OfCrop and Soil Science, Cornell University, Ithaca, NY. $418 \mathrm{hlm}$.
Fan, J., Yang, G., Zhao, H., Shi, G., Geng, Y., Hao, T., and Tao, K. 2012. Isolation identification and characterization of a glyphosate-degrading bacterium, Bacillus cereus CB4, from soil. Journal of Genetic and Applied Microbiology. 58:263-271.

Fuady. Z. 2010. Pengaruh Sistem Olah Tanah dan Residu Tanaman Terhadap Laju Mineralisasi Nitrogen Tanah. J. Ilmiah Sains dan Teknologi 10 (1):94-101.

Jenkinson, D.S., and D.S. Powlson. 1976. The Effect of Biocidal treatments on Metabolism in soilV. Fumigation with chloroform. Soil Biol. Biochem. 8:209-213.

Johnshon, G.V. 1914. Causes and Effects of Soil Acidity. Oklahoma state University. Division of Agricultural Sciences and Natural Resources. $2239 \mathrm{hlm}$.

Lubis. K. S. 2007. Aplikasi Suhu dan Aliran Panas Tanah. Fakultas Pertanian Sumatra Utara. Medan. $223 \mathrm{hlm}$.

Nursyamsi, D., J. S. Adiningsih, Sholeh dan A. Adi. 1996. Penggunaan Bahan Organik Untuk Meningkatkan Efisiensi Pupuk N dan Produktivitas Tanah Ultisol di Sitiung, Sumbar. J. Tanah Trop. 2:26-33.

Pratiwi, T. D. 2013. Pengaruh Pengolahan Tanah dan Pemberian Mulsa Bagas terhadap Kandungan Biomassa Karbon Mikroorganisme Tanah (C-mik) pada Lahan Pertanaman Tebu Tahun Kedua. Skripsi. Universitas Lampung. $52 \mathrm{hlm}$.

Rao. N.S.S. 1994. Mikroorganisme Tanah dan Pertumbuhan Tanaman. Universitas Indonesia (UI-Press). Jakarta. $353 \mathrm{hlm}$. 
Salam, A.K. 2012. Ilmu Tanah Fundamental. Global Madani Press. Bandar Lampung. $156 \mathrm{hlm}$.

Sumarsih, S., 2003. Mikrobiologi Dasar. Universitas Pembangunan Nasional Veteran, Yogyakarta. $252 \mathrm{hlm}$.

Utomo, M. 1990. Budidaya Pertanian Tanpa Olah Tanah, Teknologi Untuk Pertanian Berkelanjutan. Direktorat Produksi Padi dan Palawija. Departemen Pertanian RI. Jakarta. $168 \mathrm{hlm}$.

Utomo, M (a). 2012.Tanpa Olah Tanah Teknologi Pengelolaan Pertanian Lahan Kering. Lembaga Penelitian Universitas Lampung. Bandar Lampung. $110 \mathrm{hlm}$.

Utomo, M (b). 2012. Olah Tanah Konservasi: Teknologi Mitigasi Gas Rumah Kaca Pertanian Tanaman Pangan.Lembaga Penelitian Universitas Lampung. Bandar Lampung. Hal 3-4. 